\title{
Positional Approach to the Political Elite Criteria Selection in Democratic States
}

\author{
Vera V. Murugova ${ }^{1}$, Andrey V. Skorobogatov $^{2}$, Irina V. Bagaeva ${ }^{3}$, Natalya V. Volkova ${ }^{4}$, Vera A. Pavlova ${ }^{1}$, Valery $^{2}$ \\ P. Zhuravlev ${ }^{4} \&$ Nina D. Apraksina ${ }^{5}$ \\ ${ }^{1}$ Kazan Cooperative Institute (Branch) of the Russian University of Cooperation, Kazan, Russia \\ ${ }^{2}$ Institute of Economics, Management and Law, Kazan, Russia \\ ${ }^{3}$ Nizhnekamsk Institute of Chemical Engineering, The Branch of Kazan National Research Technological \\ University, Nizhnekamsk, Russia \\ ${ }^{4}$ Kazan (Volga region) Federal University, Kazan, Russia \\ ${ }^{5}$ Almetyevsk State Oil Institute, Almetyevsk, Russia \\ Correspondence: Vera V. Murugova, Doctor of philosophy, Associate professor of Liberal arts of Kazan \\ Cooperative Institute (Branch) of the Russian University of Cooperation, 420081, N. Ershova Street, 58, Kazan, \\ Russia. E-mail: otvet1512@mail.ru
}

Received: May 7, 2015 Accepted: May 16, 2015 Online Published: May 28, 2015

doi:10.5539/jsd.v8n3p271 URL: http://dx.doi.org/10.5539/jsd.v8n3p271

\begin{abstract}
The relevance of the research problem is justified by the fact that contemporary political experts consider the political process of democratic ruling elite forming as in Russia so in other countries only in general aspects and there is no unified understanding of this process. The aim of this article is to summarize the scientific knowledge on the problem under consideration and to propose criteria for political elite selection in democratic States. A leading approach to this problem study is a positional approach. From the point of view of the positional approach the political elite is defined as the range of persons who has attained powerful positions and who has the right of direct participation in the process of government decision-making through open competition for votes and political elections' win in representative bodies of power. The article can be useful for political scientists and sociologists studying the problems of political elites' formation and functioning.
\end{abstract}

Keywords: political elite, a positional approach, formation, criteria of selection, democratic state

\section{Introduction}

\subsection{The Relevance of the Problem}

The study of government and political entities, who possesses it since ancient time has occupied a central point in political science. And, despite the fact that the theory of the elites' reign in political science appeared relatively recently - in the late XIX - early XX century, they became widespread and took a prominent place among other political theories that explain the principles of organization and functioning of power in society. Studies of the ruling elites are widespread in democratic States. Most Western political scientists who study the ruling elites agree that when democratic governance the presence of one or more groups, possessing all the attributes of the ruling elite and directly or indirectly involved in the decision making process at the state level, is an objective reality, due to the peculiarities of the democratic system.

The implementation of direct democracy in modern states is impossible. Representative democracy, which became the main form of government, with its inherent system of institutions formation through delegation by the citizens through elections of their powers to manage the state's limited and relatively small number of representatives, leads to the fact that there is a narrow circle of professional politicians and high-ranking officials, who perform management functions at the state level. This is the group of people who is the ruling elite. The situation is similar at the level of management with territorial units which are parts of the state (i.e. at the level of regions), where in the framework of democratic institutions and procedures the regional ruling elite is formed. It is the middle level in the hierarchy of state administration. At the lower level are those who are included in the local government. 
In the late 80 's - early 90-ies the formation of democratic institutions began in Russia.

Adopted in 1993, the Constitution of the Russian Federation finally established democratic way of development of Russia and institutionalized state structure and system of government. At the same time began to form a new ruling elite began to form. Almost 70 years of totalitarianism period had ended by the twentieth century in Russia and the transition period to a democratic form of government began, which resulted in fundamental changes in government. As a result of the conflict between the executive and legislative branches of government which led to the tragic events of October 3-4, 1993, representatives of Executive authorities of Russian regions became more important on the Russian political arena. There was a strengthening of the regional ruling elites' position, their influence on the Russian political process increased. This attracted attention of Russian political scientists to regional elites, the number of studies devoted to the analysis of the ruling elites of separate regions and to the problems in general dramatically increased. The study of regional elites became one of the leading directions of domestic politics development.

\subsection{Explore Importance of the Problem}

Most researchers recognized that in Russia there changes took place as in processes and mechanisms of the ruling elite formation so in its characteristics, i.e. the formation of a new elite occur that met the requirements and conditions of the modern period of development in the country. The structure of the ruling elite was changed, formed a new government institutions were formed, its social composition was changed. A multi-party system and finance-industrial groups, based on private property became important in modern ruling elite development. But at the same time, the new ruling elite of Russia borrowed much from its predecessor - party-economic nomenclature of the era of "stagnation". This is particularly noticeable in the analysis of intra-elite interactions and due to the fact that the ruling elite in the 90-ies included many members of the middle level of the Soviet nomenclature (Krishtanovskaya, 2005).

Since the last years of the last century the problem of regional ruling elites gave rise to a great interest among Russian political scientists. There are many works which are devoted as to the analysis of regional elites in general (Krishtanovskaya, 2003; Gudkov, Dubin \& Levada, 2007, Ohotski, 2006) so to the study of ruling elites in certain regions of Russia (Prokofieva, 2004; Polyakov, 2004; Alekseenko, 2011; Hanin, 2012). In these researches, the peculiarities of regional elites forming, their structure and social structure, their functioning are taken into consideration, the comparative analysis of the ruling elites in various Russian regions is given, as characteristics which are common to the Russian regional elites, so to the elites of separate regions are revealed. Researchers agree that the ruling elite of almost all Russian regions were formed from representatives of mid-level regional economic and party leaders of the Soviet period in accordance with the ideological goal setting for independence from the Federal government and democratic reform taking into account the priority of the region's interests. In many Russian regions clan model of the ruling elite with authoritarian mechanisms of inter-elite interaction and control methods was formed. Moreover, the dominant role in the political process of the regions belonged to Executive power.

It is important to note the fact that there is no a clear definition of the ruling elite or political elite in modern Russian political science. In this paper, the ruling elite means the range of persons who due to their official authority carry out administrative functions and participate in the process of development, adoption and implementation of political decisions at the Federal level (Federal, Russian ruling elite) or at the regional level (regional ruling elite). Consequently, the regional ruling elite consists of representatives from the regional administration (the Executive power), deputies of the regional legislative Assembly (representative authority) and deputies of the Russian Federation State Duma elected from their region, as representatives of its interests at the Federal level. The ruling elite according to the recruitment method and functions, tasks and ways of their solution is divided into administrative elite (the Executive power) and the political elite (members of legislature).

\subsection{Hypotheses of the Research}

The political elite mean the persons who have reached positions of power and who has the right of direct participation in the process of political decision-making through open competition for votes and win elections in representative bodies.

\section{Methodological Framework}

\subsection{Objectives of the Research}

The following tasks were solved during the research: 1) the theoretical analysis of scientific literature on the research topic; 2) an analysis of the concept of the political elite in different directions of political thought; 3 ) analysis of criteria for political elite selection; 4) criteria analysis from the point of view of the positional 
approach 5) the analysis of the obtained data, its theoretical conceptualization, formulation of the author's understanding of the notion of political elites and the criteria for its selection.

\subsection{Theoretical Methods}

To test the hypothesis a complex of various theoretical methods, which are complementary to each other, was used: literature analysis, regulatory, legislative, guidance, work documents, and materials of managerial and procedural nature of the research problem; reviewing and summarizing of innovative political science and political experience, analysis, synthesis.

\subsection{Methodological Basis of the Research}

Methodological basis of the research is a positional analysis, that is, belonging to the political elite is detected on the basis of a post. The paper also uses elements of comparative analysis, sociological analysis and content analysis.

\section{Results}

\subsection{Causes of Elitist Rule in Democratic States}

The elites ruling is the reality of the political life of States, built on the basis of democratic principles. But there are a number of objective reasons:

1. The impossibility of democracy implementation as direct democratic way of ruling and the impossibility of total control over the activities of the authorities by the population;

2. The existence of the law of labor social division, whereby managerial and political activity is a separate activity requiring special knowledge, skills and professionalism;

3. The control system in itself implies the presence of those who govern and those who is governed; this system is effective when the governing less than the governed;

4. Different abilities and skills of people, the priority of most everyday vital interests over political for the majority;

5. The established in the public mind of stereotypes about the being prestige and impossible to reach of political and managerial positions

\subsection{The Main Approaches to the Political Elite Phenomenon Understanding}

In modern political science, there are a number of opinions about what is the political elite, which can be classified in four groups.

1. Supporters of left-liberal elites' concepts (machiavellists school), abiding by the basic postulates of classical elitism, believe that the company has a single, cohesive elite of few members, whose existence is due to the law of social division of labor. The elite consist of people occupying the highest and most prestigious status positions. The ruling elite in any society has a monopoly on decision making. This minority held a leading position in society, not because of the election, but as a result of dominance in the field of economy or the coup implementation. Elections only draw power as actually unaccountable to the masses elite, and never turn into an effective controlling mechanism over its activities. The goal of the elite is stability maintaining in the existing situation in society, in the existing social order within which they have power. There is an abyss between the elite and the masses, which is virtually impossible to overcome for the natives of non-elite environment, because elites are formed mainly of representatives of the higher social strata and under the control of the ruling group (Gaman-Golutvina, 2008).

2. Proponents of valuable theories (meritocratic approach) argue that the modern society elite consist of people who are best able to understand the social and public life and to make the right decisions. This is the most productive and enterprising part of the population, besides of it they usually have higher moral aspirations. Elite is formed by means of natural selection among the best representatives of the society with the most valuable qualities for society. Equality of opportunities during democracy gives them a real chance to achieve the best results in their activity and become elite. Changes in the elite occur when demands and value orientations in society are changed. The most valuable qualities' carriers of passing time are replaced by people whose qualities meet the new requirements. So noble, educated, with sense of honor aristocracy of traditional societies gave way to enthusiastic and enterprising bourgeoisie of capitalism, and it, in turn, gave way to a highly educated, informed and able to manage "managers" of the postindustrial era. The elite, as a moral benchmark for the population, has authority, and thereby performs the functions of not domination but control, with the consent and approval of the masses, which they express during the elections. The ideal of elites' value theories is a healthy 
peaceful society with the inevitable hierarchical structure in which the individual has the happiness of knowing his place, and elite is the inner authority" (Ashin, 2003).

3. Democratic elitism theory followers understand democracy as an institutional tool for political decisions achieving on the basis of which separate individuals get the power to make decisions by competition, the object of which are the voices of voters. In the understanding of elites they largely follow a tradition of a machiavellism school. So, they believe that the power is concentrated in the hands of a minority and it means the control of major resources. But they argue that the elite to be more close to fundamental democratic values. It is the guarantor of the democratic political system existence and restrains antidemocratically configured mass. But if the elite is left without control by the masses (through elections, referendums, etc.), then there is a danger of it becoming a closed privileged caste, infinitely dominating in the society. Democratic institutions are necessary to preserve the elite's responsibility for the pursued policies. Elite operates in the political sphere, and it is made of professional politicians who have gained power through the competition for votes (Ashin, 2003).

4. Supporters of the elites' pluralism concept insist that in a modern democratic society there is no single ruling elite. They say that power is dispersed and concentrated in the hands of various elite groups ("stakeholders"), which compete for control over resources of power and determine policy alternately, depending on what problems are solved. No single elite dominates in all spheres of public life. The pluralist democracy model purport to be a complete description of the democratic process in modern industrial countries, in which due to technical (not social) reasons direct democracy can't be fulfilled. Although the individual is not directly involved in the government policy making, it is assumed that he may enter the formal organization, able to influence the government in the necessary direction. Plurality assume that the differentiation of modern society, including a large number of groups - professional, religious, ethnic, regional, etc. - creates the potential for the formation of organizations, expressing their differentiated interests. They also rely on the concept of powers separation, resulting in a system formation in which the authorities can keep each other from tyranny in society. The boundaries between elite and mass are blurred, access to the elite is open to all who are interested in participating in the process of political decision-making. Masses have a great impact on the elite, and strong competition makes elites responsible to the people (Ashin, 2003).

Thus, we can conclude that there is no a single point of view on the question of what is the ruling elite in a democratic society in the Western political science today. There is no a single definition of concepts, there is no common understanding of the structure, mechanisms of formation and roles of elites. But nevertheless it is possible to allocate more or less common to most researchers features of the democratic elite and the criteria by which is defined. The ruling elite in a democratic society is a small, relatively closed group of persons (equality of opportunities makes pretty real the vertical mobility and joining the elite of new professional staff) engaged in the management of the company. Within the elite, there is a certain equality of social positions, capitals, global interests' unity and goals. Its members are mainly are representatives of the higher strata of society, united around the most influential persons in politics, economy, industry, army. Made in such way intra-elite groups compete with each other for the adoption of certain decisions and decisions are made through consensus between them. A global agreement within the elite exists on the preservation of a democratic system of governance in society and a stable socio - political, economic and social development of society. The ruling elite is actually independent from the society, but this the very democracy allows the public to control its activities through elections, referenda, sanctioned rallies, through joining in "interest groups, trade unions and via other means of citizens rights' expressing to participate in political decision-making.

Also during the democratic government, there is another equally important factor in the control of the ruling elite - the existence of a free opposition and its leadership - counter-elite. Counter-elite has the same characteristics as the ruling elite, except of one - the access to instruments of power, and determines the programme and methods of work of opposition parties and movements. There may be one Counter-elite (for example, in countries with two-party system where one party is in power, and the other seeks to change it in this post), or there may be several of them, if there are several popular opposition political movements and parties with different ideological and policy orientations in the state. The main task of the counter-elite (or elite) - to gain access to power through political struggle with the existing elite. In opposition to the ruling elite, counter elite represents an important internal source of elite development, the structural factor that prevents the shortcomings of a person being at the pinnacle of power, to become the vices of the state system. The elite in power, has to take into account criticism from the opposition, otherwise, in case of dissatisfaction with its policy by population, the counter-elite can win in the elections and displace the ruling elite, from its hold on power.. Thus, the counter-elite is one of the main factors constraining the elite in a democratic society from degenerating into a closed caste, and from neglecting the interests of society. 


\subsection{The Ruling Elite Selection Criteria}

- The main criteria according to which modern science distinguishes the ruling elite, are the following:

- access to power tools and resources;

- impact on the political course of events;

- being involved directly in development, adoption and implementation of important state decisions through the appropriate authorities;

- deep inner connection of its members, both horizontal and vertical, commonality of their interests.

But there is some confusion in modern political science as to the question of what to call the ruling elite, political elite, and so on. Very often under the political elite we understand the whole circle of people occupying leading positions in the political arena: as famous political figures, members of the legislative Assembly, the leadership of the major political parties, senior government officials, so those who occupy the highest positions in state administrations (presidential, governmental, etc.), and sometimes large financiers, Industrialists, i.e. all those who directly or indirectly affect the political process. But in our view, there is a substitution of concepts here. All those who have access to the tools of power and influence policies in accordance with their interests, can be combined by the concept of the "political class". It is the circle of persons exercising political and administrative functions. It includes government workers at all levels, elected and appointed personnel of all branches of government, management and staff services of political parties and public organizations and movements, as well as representatives of all those social forces that may directly or indirectly influence the held policy in the state. The ruling elite (the ruling and not having power, because, as it was noted above, during a democracy, the elite fulfils managerial, not powerful activities) is the highest level in the hierarchy of all those who are in the political class. The ruling elite according to the method of recruitment and the style of activity (functions, tasks and ways of their solution) can be divided into administrative and political. Administrative elite consists of officials who were appointed on their posts. Its representatives has real powers, have certain social status, the required professional training, so it is an organic unity, the main characteristics of which are power, prestige, group thinking, a sense of belonging to the caste of the elite. In this environment political aims of the programme are formed (but it should be noted, responsible and important decisions are not taken), and they are implemented under its leadership. The members of the administrative elite are not involved in the political struggle, they are busy in the management of the economy, industry, defence, social sphere and so on. (That is, it is the Executive power of the government and the administration at various levels: Federal, regional, local).

The political elite are those who are directly involved in the political struggle and come to power through elections. They do legislation, make important public and political decisions, the execution of which is entrusted to administrative elite (that is, representative government, deputies of the legislative Assembly).

- Criteria for the political elite selection:

- political mechanism of recruitment, participation in the political struggle;

- direct participation in making political decisions and government;

- constant open competition for the legitimate possession of the resources and power etc. the struggle for voters' voices.

\section{Discussions}

Based on the above it can be concluded that from the point of view of the positional approach in a democratic society there is a fairly broad "political class", the leadership of which represents the ruling elite. It, in its turn, is divided into the administrative and political elite. The political elite can be defined as the range of persons who have attained positions in power and who has the right of direct participation in the process of government decision-making through open competition for votes and win political elections into representative bodies.

\section{Conclusion}

The conclusions made in this paper and based on the analysis of the political elite allow us to better understand the processes of modern Russian regional elites' formation. They can be used in research and teaching practice in the study of political power, political institutions and ruling elites.

\section{References}

Alekseenko, I. A. (2011). Socio-historical characteristics of the regional political elite on the Altai territory. (Unpublished master's thesis) Altai state University. Barnaul, Russia. 
Ashin, G. K. (2003). The course of lithology history. Moscow. MGIMO (University).

Ashin, G. K. (2005). The elites change. Social Sciences and modern time. Moscow. AST.

Ashin, G. K. (2008). Democratic elitism. Moscow. The Power.

Gaman-Golutvina, O. V. (2008). The political elite of Russia. Moscow. Nauka.

Gudkov, L., Dubin, B., \& Levada, Y. (2007). The problem of the "elite" in Russia today. Moscow. Nauka.

Khanin, D. I. (2012). Regional political elite in the conditions of behind-Baikal territory. (Unpublished master's thesis) Behind-Baikal state University. Сhitaю Russia.

Kryshtanovskaya, O. V. (2005). Anatomy of the Russian elite. Moscow. Zakharov.

Kryshtanovskaya, O.V. (2003). The formation of regional elites: principles and mechanisms. Sociological research, 11, 3-13.

Okhotsky, E. V. (2006). The political elite and the Russian reality. Moscow. Flinta.

Polyakov, A. V. (2004). Regional political elite as an entity of political process: On materials of Krasnodar territory. (Unpublished master's thesis) Branch of Russian state social University. Krasnodar, Russia.

Prokofieva, Y. V. (2004). The institutionalization of the political elite in modern Russia: Regional aspect. (Unpublished master's thesis) Saratov state technical University. Saratov, Russia.

Sidakov, A. M. (2012). The Russian political elite in modern conditions. (Unpublished master's thesis) North Caucasian state humanitarian-technological Academy. Stavropol, Russia.

Voskanyan, S. S. (2004). The political elite of post-Soviet Russia: problems and processes of formation, change and development. (Unpublished master's thesis) Volgograd branch of the Management Institute, Voronezh, Russia.

\section{Copyrights}

Copyright for this article is retained by the author(s), with first publication rights granted to the journal.

This is an open-access article distributed under the terms and conditions of the Creative Commons Attribution license (http://creativecommons.org/licenses/by/3.0/). 